\title{
Evaluation of Formaldehyde Emission from Wood-Based Panels Using Accelerated Collection Method ${ }^{1}$
}

\author{
Hyun-jo $\mathrm{Han}^{2} \cdot$ Seog-eon Lee ${ }^{3} \cdot$ Seung-min Yang $^{4} \cdot$ Chul Choi $^{4} \cdot$ Seog-goo Kang ${ }^{4}{ }^{4, \dagger}$
}

\begin{abstract}
This study aimed at developing an accelerated collection method that reduces measurement and collection time by improving and complementing the desiccator method, which is mainly used for quality control in wood-based panels and furniture production sites. First, this study measured the formaldehyde emissions from the wood-based panels by grade using the desiccator method. Further, this study compared the desiccator method with the developed process and analyzed the correlation in optimal temperature, time, and exposed area. The results showed that the developed process resulted in relatively similar outcomes in comparison to the desiccator method when the temperature was 100 ${ }^{\circ} \mathrm{C}$, the time was $1 \mathrm{~h}$, and two specimens were used, at which the correlation was high. To verify the developed process, this study commissioned Korea Conformity Laboratories with the standardized temperature, time, and the number of specimens to compare them with the specimen that was not used in the actual test. As a result, the correlation to the desiccator method was shown to be very high. However, the formaldehyde emission measured by the accelerated collection process was mostly higher than that measured by the desiccator method. The formaldehyde emission grades from several specimens were one level higher. However, from the perspectives of quality control, it was determined that the accelerated collection method developed in this study could be sufficiently used.
\end{abstract}

Keywords: formaldehyde, wood-based panel, accelerated collection method

\section{INTRODUCTION}

Thanks to the improvement in the quality of life among South Korean people, there has been a growing interest in housing environment, such as DIY furniture and interior remodeling. Accordingly, the furniture market has recently shown a continuous growth, and as a result, the use of medium density fiberboards (MDFs) and particle boards (PBs), which are the raw materials for furniture, has also increased. Since the entrance of global furniture company IKEA to South Korean market in 2014, the overall growth of the furniture industry as well as the increase in the use of one- or two-person households, the expansion of the remodeling market, as well as the increase in the use of pallet have led to the overall production and import of, and demand on PBs and MDFs (Korea Trade Commission in Ministry of Trade, 2016).

\footnotetext{
${ }^{1}$ Date Received November 15, 2018, Date Accepted January 14, 2019

${ }^{2}$ Wood \& Furniture Research Center, Korea Conformity Laboratories. Incheon 21591, Republic of Korea

${ }^{3}$ Industrial \& Environment Business Team, FITI Testing \& Research Institute, Ochang-eup 28115, Republic of Korea

${ }^{4}$ Department of Bio-based Materials, Chungnam National University, Daejeon 34134, Republic of Korea

† Corresponding author: Seog-goo Kang (e-mail: lachesis@cnu.ac.kr, ORCID: 0000-0002-2440-7070)
} 
The manufacturing process of MDF and PD is as follows: waste wood or raw wood materials are processed into particles or textile; adhesives are applied to them; and they are dried, formed, and heat-pressured. The adhesives used here are amino-group resin adhesives like urea-formaldehyde resin and melamineurea-formaldehyde resin, which induce the combination of chips or fiber and are key elements of boards, to form boards (Meyer et al., 1985). Formaldehyde, one of the key materials for adhesives is regulated as class 1 carcinogen by WHO, and many other countries control the emissions or daily intake of this harmful substance. By examining the effect of formaldehyde exposure on human body, it was noted that short-term exposure to formaldehyde strongly irritates the respiratory system and mucous membranes, and causes dizziness and headache. Long-term exposure to formaldehyde would cause respiratory diseases such as rhinitis, asthma, bronchitis, allergic contact dermatitis, and cancer (Nelson, 1986).

Therefore, formaldehyde is controlled by the South Korean government with the enactment of the indoor air quality control act by the Ministry of Environment in 2004 and South Korean people's interest in its effect has grown. The indoor air quality control act regulates all products used in daily life such as furniture, indoor flooring, and finishing materials (Jang et al., 2017). In addition, since 2016, Korean Standard (KS) regulates wood materials used indoor to be E0 or below, and globally, the formaldehyde emissions regulations have been established on wood-based boards. While each country has different measurements on standard formaldehyde emissions, the regulations are becoming stronger along with the more stringent environmental regulations (Park et al., 2005).

As such, not only South Korea, but countries globally recognize the risk of formaldehyde emitted indoors and continue to strengthen regulations on formaldehyde emissions. Formaldehyde emissions can be measured by various methods, such as perforator, desiccator, or small chamber method used in South Korea. The desiccator method, which has been standardized and used for a long time in South Korea, is the simplest and less expensive for testing. Due to this, it has often been used for quality control in manufacturing plants. However, it cannot measure HCHO and VOCs. Small chamber method can measure formaldehyde emissions under a constant amount of ventilation close to the actual indoor space and allows for the measurement of $\mathrm{HCHO}$ and VOCs. However, measurement takes long time and is based on the measurement of the surface emissions so that compared to the desiccator method wherein four sides are exposed, it results in under-evaluation of formaldehyde emissions. Furthermore, highly specialized techniques are required for analysis and the analysis equipment (e.g., HPLC and GC/MS) is expensive. As mentioned, in South Korea, most manufacturing plants are standardized to the desiccator or small chamber methods, which are used in various certification and regulation processes.

Since the enactment of the act on the sustainable use of wood in 2013, the quality control of wood-based plates is compulsorily done via the desiccator method according to the specifications and quality standards of the wood products. Moreover, according to the research due to continuous interest and risks in indoor air environments, the Ministry of Environment grants environmental certification marks for the small chamber method and desiccator method. Based on the standard specifications for the environmental certification marks for furniture or flooring materials, and the furniture supplier conformity standard (KC) by the Ministry of Trade, Industry and Energy allows the suppliers or importers to select one of the two methods so that they can directly control them.

Accordingly, industries that produce or use woodbased plates use the desiccator method for quality control, which allows for convenient and easy testing 
at sites due to the lack of specialist requirement and spatial limitations. In contrast, the small chamber method requires expensive equipment and specialists. While the desiccator method allows for quick tests for measuring emissions compared with other formaldehyde emissions test methods, it requires $24 \mathrm{~h}$ of collection time. Thus, it cannot be immediately used in quality control at production sites. Therefore, it is necessary to develop a method that allows for immediate quality control, simple analysis, and fast determination of the concentration of formaldehyde emissions.

Therefore, this study aimed to develop an accelerated collection method that reduced the measurement and collection time by revising and complementing the desiccator method primarily used in quality control of wood-based plates and in furniture manufacturing sites and to evaluate the formaldehyde emissions by the implementation of the developed accelerated collection method. This study managed to develop an accelerated formaldehyde collection process that allowed fast and accurate measurement based on the advantages of the desiccator method, offering easy analysis, and the advantages of the small chamber method, allowing the measurement of formaldehyde emissions by applying the amount of ventilation close to the actual indoor space. Moreover, this study verified the applicability of the developed process to wood-based plates and furniture manufacturing sites by comparing the characteristics of the formaldehyde emission measurement by the desiccator and small chamber methods.

\section{MATERIALS and METHODS}

\subsection{Specimens}

MDFs used in the test were $4.5 \mathrm{~mm}, 15 \mathrm{~mm}$, and $18 \mathrm{~mm}$ in thickness, which were often used for furniture and other interior products, and the thicknesses of the applied PBs were $15 \mathrm{~mm}$ and $18 \mathrm{~mm}$. MDFs were received from Company A in Incheon while PBs were from Company B in Incheon. The properties of the used materials were tested to be suitable based on the density and moisture content ratio of PBs (KS F 3104, 2016) and MDFs (KS F 3200, 2016), the results of which are shown in Table 1.

\subsection{Accelerated formaldehyde collection process design}

To quickly and accurately collect formaldehyde emitted from wood-based plates, this study divided the area into three sections: the air injection part, the volatilization part, and the collection part. The air injection part is linked to 12 air injection pipes so that the air produced by an air compressor can be emitted

Table 1. Physical properties of medium density fiberboards (MDF) \& particle boards (PB).

\begin{tabular}{|c|c|c|c|c|c|c|}
\hline \multirow{3}{*}{$\begin{array}{l}\text { Physical } \\
\text { properties }\end{array}$} & \multirow{3}{*}{$\begin{array}{l}\text { HCHO } \\
\text { Grade }\end{array}$} & \multicolumn{5}{|c|}{ Wood-based panels } \\
\hline & & \multicolumn{3}{|c|}{ MDF } & \multicolumn{2}{|c|}{ PB } \\
\hline & & $4.5 \mathrm{~mm}$ & $15 \mathrm{~mm}$ & $18 \mathrm{~mm}$ & $15 \mathrm{~mm}$ & $18 \mathrm{~mm}$ \\
\hline \multirow{3}{*}{$\begin{array}{l}\text { Density } \\
\left(\mathrm{g} / \mathrm{cm}^{3}\right)\end{array}$} & E2 & 0.68 & 0.54 & 0.54 & 0.69 & 0.70 \\
\hline & E1 & 0.68 & 0.57 & 0.56 & 0.70 & 0.69 \\
\hline & E0 & 0.66 & 0.56 & 0.55 & 0.69 & 0.70 \\
\hline \multirow{3}{*}{$\begin{array}{l}\text { Moisture } \\
\text { Content } \\
(\%)\end{array}$} & E2 & 5 & 5 & 5 & 5 & 5 \\
\hline & E1 & 5 & 5 & 5 & 5 & 5 \\
\hline & E0 & 5 & 5 & 5 & 5 & 5 \\
\hline
\end{tabular}




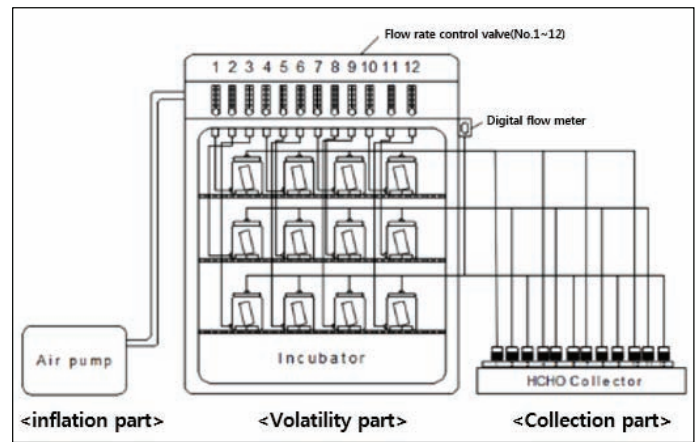

Fig. 1. Mimetic diagram of accelerated formaldehyde collection process system (Samheung energy Co., Korea).

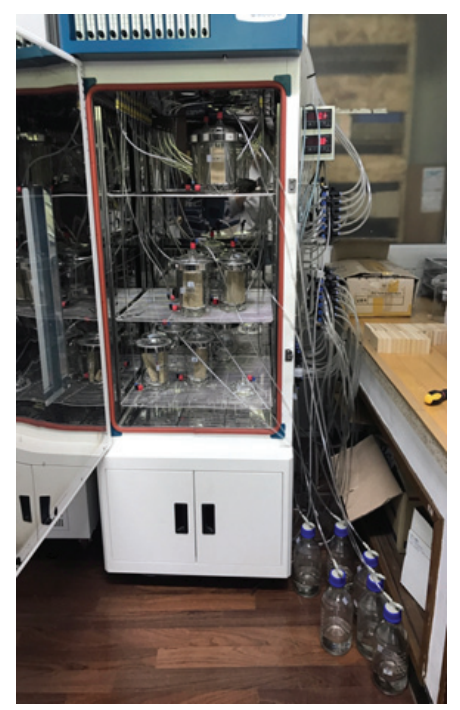

Fig. 2. Actual device of accelerated formaldehyde collection process system.

through them, and to a control valve is installed to control the air flow. The volatilization part used a transparent glass container offering high heat absorption rate and temperature control inside the incubator; a rubber ring was installed between the glass bottle and the cover to prevent the leakage of formaldehyde. To prevent the specimen inside the volatilization part of the glass bottle from blocking the injected air, a specimen support plate was placed for smooth air flow.
The collection part has a digital air flow measurement device to measure the flow of air emitted through the installed pipe, and GL45 by DURAN was used to connect between the glass bottle at the collection part and the polyurethane pipe. Fig. 1 should the schematic of the air injection, volatilization, and collection parts of wood-based plates, and Fig. 2 shows the actual test.

\subsection{Formaldehyde emission measurements by on the desiccator method}

To determine the formaldehyde emissions from the wood-based plates used in the test, the study conducted a test based on the formaldehyde emission test method (KS M 1998, 2017). The number of specimens based on the surface area of each board $\left(1,800 \mathrm{~cm}^{2}\right)$ was determined, and the pre-process was conducted for seven days at $20 \pm 2{ }^{\circ} \mathrm{C}$ and $65 \pm 5 \%$ relative humidity until the mass change ratio of the specimens reach at or below $0.1 \%$. After the pre-processing, the specimens were inserted into distilled water (300 mL) inside the desiccator, and formaldehyde was collected at $20 \pm 1$ ${ }^{\circ} \mathrm{C}$ for $24 \mathrm{~h}$ inside a thermo-hygrostat. The distilled water absorbed formaldehyde forming acetylacetone, which was measured using a spectrophotometer at the wavelength of $412 \mathrm{~nm}$.

\subsection{Development of the accelerated collection method}

\subsubsection{Selection of the optimal temperature and time}

The test used the collection test device, designed according to the accelerated collection method for the wood-based plates. The size of specimens and test conditions for the application of the accelerated collection method are as follows.

In the desiccator method, the number of the specimens in $5 \mathrm{~cm} \times 15 \mathrm{~cm}$ is determined based on the surface 
area of $1,800 \mathrm{~cm}^{2}$ with the size of the desiccator being $11 \mathrm{~L}$. This was done considering in the test device, the size of the glass bottle in the volatilization part is $1,000 \mathrm{~mL}$, the size of the specimen surface area inside the glass bottle of the volatilization part was reduced to $1 / 11$, and the specimens at $5 \mathrm{~cm} \times 15 \mathrm{~cm}$ were used to set the exposure surface area to $163 \mathrm{~cm}^{2}$.

Subsequently, the test conditions for the accelerated collection method are as follows. According to Park (2004), and Lee and Kim (2012), the formaldehyde emission test by the desiccator method showed the increase in the emissions as the measurement temperature increased. Also, Kim (2012) pointed out that the measurement of the formaldehyde collection ratio by volatilization temperature and the amount of nitrogen at the device separating the volatilization and collection parts, as a method for fast detection of formaldehyde mixed in wood and feed, showed that the amount of nitrogen was $40 \mathrm{~cm}^{3} / \mathrm{min}$, and the maximum collection ratio of $94.8 \%$ at $100{ }^{\circ} \mathrm{C}$ for $30 \mathrm{~min}$.

Based on previous studies, the test conditions for developing the accelerated collection method that reduced the measurement and collection time, the ultimate aim of this study, were the amount of air flow at $40 \mathrm{~cm}^{3} / \mathrm{min}$, the temperature at $100{ }^{\circ} \mathrm{C}, 60{ }^{\circ} \mathrm{C}$, and $25{ }^{\circ} \mathrm{C}$ for the formaldehyde emissions to compare the formaldehyde emission properties between the accelerated collection method and the desiccator method by temperature and time.

\subsubsection{Effect of exposed area of specimens}

The formaldehyde emissions may change based on the specimen surface area of the wood-based plates and collection time when testing formaldehyde emissions by the desiccator or small chamber methods. In the former case, the standard conditions were 1,800 $\mathrm{cm}^{2}$ for the specimen's exposed area and $24 \mathrm{~h}$ for the collection time, and in the latter case, the emission value is determined by the amount of the unit area $\left(\mathrm{g} / \mathrm{m}^{2} \cdot \mathrm{h}\right)$ in time when showing the emission results to identify the standardized value against the evaporated amount of formaldehyde emissions. Therefore, it was determined that the accelerated collection method in this study needed to find the exposed area of the standardized specimens and the optimal collection time.

Therefore, this study aimed to reduce the collection and evaporation process time by increasing the surface area of the specimen exposed to the volatilization in the collection process is designed to have two (163 $\left.\mathrm{cm}^{2} \times 2\right)$ or four $\left(163 \mathrm{~cm}^{2} \times 4\right)$ specimens with their exposed surface area set to $163 \mathrm{~cm}^{2}$ during the formaldehyde emission test with the temperature and time set to improve the efficiency of the collection and volatilization processes. Using the collection test device designed according to the accelerated collection method, the study compared its formaldehyde emission properties based on the exposed area with those of the desiccator method.

\section{RESULTS and DISCUSSION}

\subsection{Formaldehyde emission measurements by the desiccator method}

The desiccator method was used to measure three times the formaldehyde emissions by the grade of the formaldehyde emissions from five types of wood-based plates, MDF $4.5 \mathrm{~mm}$, MDF $12 \mathrm{~mm}$, MDF $18 \mathrm{~mm}$, PB $15 \mathrm{~mm}$, and PB $18 \mathrm{~mm}$. Fig. 3 shows the formaldehyde emission concentration measurement results in terms of the material and thickness.

\subsection{Development of the accelerated collection process}

\author{
3.2.1. Selection of the optimal temperature \\ and time \\ First, at the temperature of $25^{\circ} \mathrm{C}$ and $60{ }^{\circ} \mathrm{C}$, MDF
}




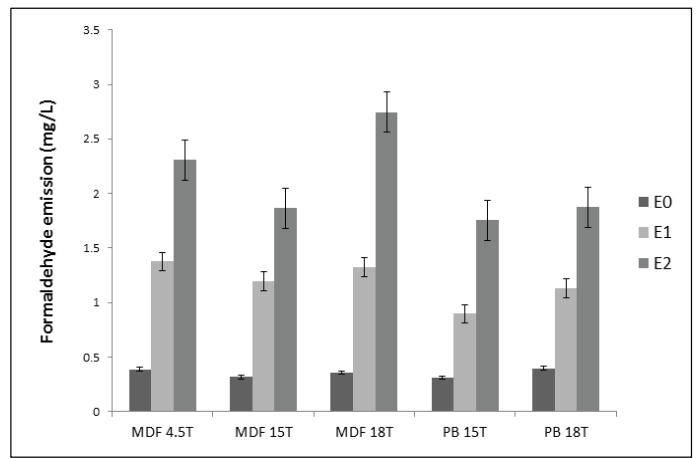

Fig. 3. Average level of formaldehyde emissions by grade in desiccator method.

$4.5 \mathrm{~mm}$ and PB $15 \mathrm{~mm}$ were used to measure three times the formaldehyde emission concentration by grade at the collection test device designed for the development of the accelerated collection method. The formaldehyde emissions from the accelerated collection test device at $25{ }^{\circ} \mathrm{C}$ for $1 \mathrm{~h}, 2 \mathrm{~h}$, and $3 \mathrm{~h}$ for MDF $4.5 \mathrm{~mm}$ and $\mathrm{PB} 15 \mathrm{~mm}$ were undetectable (detection limit: $0.05 \mathrm{mg} / \mathrm{L}$ ) for all E2, E1, and E0 grades. At $60{ }^{\circ} \mathrm{C}$, it was also undetectable for MDF $4.5 \mathrm{~mm}$ and PB $15 \mathrm{~mm}$ for $1 \mathrm{~h}$ and $2 \mathrm{~h}$. At $25^{\circ} \mathrm{C}$ and at $60{ }^{\circ} \mathrm{C}$, $\mathrm{E} 1$ and $\mathrm{E} 0$ grades were undetectable, and $\mathrm{E} 2$ grade was detected with a concentration of $0.08 \mathrm{mg} / \mathrm{L}$ for $\mathrm{MDF}$ and $0.09 \mathrm{mg} / \mathrm{L}$ for $\mathrm{PB}$.

As shown in the formaldehyde emission results from the collection device at $25{ }^{\circ} \mathrm{C}$ and $60{ }^{\circ} \mathrm{C}$, the formaldehyde emissions can only be measured at 60 ${ }^{\circ} \mathrm{C}$ and over 3 h. According to Lee and Kim (2005) on the formaldehyde emission properties of wood-based plates with time and temperature, the formaldehyde emissions continued to increase with time, and the higher the temperature, the more the width of the emission change became between six and 12 hours.

As such, to quickly measure formaldehyde emissions, which was the main aim of this study, it was determined that the collection temperature should be at $100{ }^{\circ} \mathrm{C}$, higher than the previous temperature conditions, to quickly collect evaporated formaldehyde as the evaporation

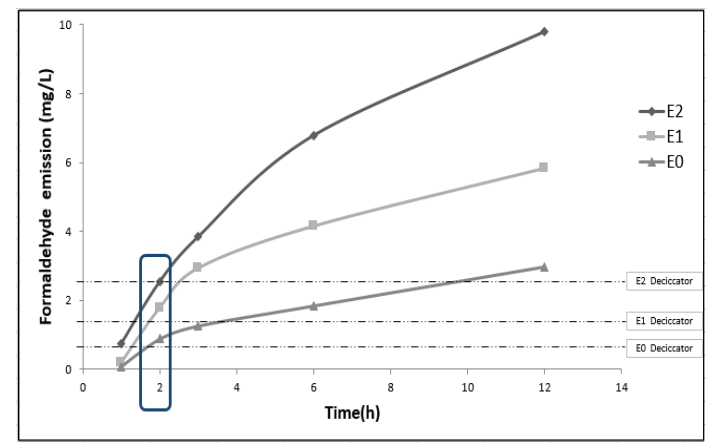

Fig. 4. Formaldehyde emissions per hour by accelerated collection method of medium density fiberboards (MDF) $4.5 \mathrm{~mm}$ at $100{ }^{\circ} \mathrm{C}$.

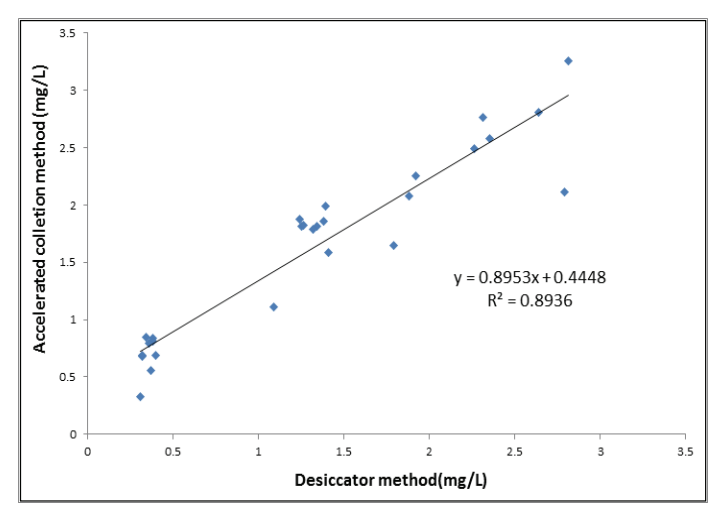

Fig. 5. Correlation of accelerated collection method with desiccator method from $\operatorname{MDF}\left(\mathrm{R}^{2}=0.8936\right)$.

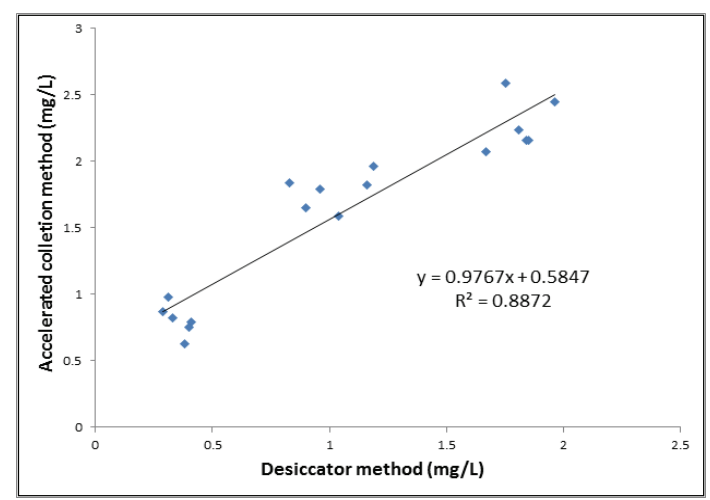

Fig. 6. Correlation of accelerated collection method with desiccator method from particle boards (PB) $\left(\mathrm{R}^{2}=0.8872\right)$. 
speed would increase.

To determine the optimal collection time at $100{ }^{\circ} \mathrm{C}$, the study first repeated the test three times with $\mathrm{MDF}$ $4.5 \mathrm{~mm}$ each for $1,2,3,6$, and $12 \mathrm{~h}$, and the results are shown in Fig. 4. At $100{ }^{\circ} \mathrm{C}$, the formaldehyde emissions by the collection test device are shown to increase with time. It was determined that when the results from the desiccator method were compared with these results, similar emission intensity was noted at 2 h. Therefore, additional tests on formaldehyde emissions were conducted with MDF $15 \mathrm{~mm}$, MDF $18 \mathrm{~mm}, \mathrm{~PB} 15 \mathrm{~mm}$, and PB $18 \mathrm{~mm}$ at $100{ }^{\circ} \mathrm{C}$ for $2 \mathrm{~h}$, and the results were compared with those of the desiccator method to determine the correlations. When the formaldehyde emissions by the desiccator method were compared to those by the developed accelerated collection method, MDF showed a high correlation with $r^{2}=0.8936$, and PB with $r^{2}=0.8872$ (Figs. 5 and 6).

\subsubsection{Effect of the specimen's exposed area}

Based on the formaldehyde emission results with changes in temperature and time, these were shown to have a similar emission intensities to those of the desiccator method with the exposed area of $163 \mathrm{~cm}^{2}$, temperature of $100{ }^{\circ} \mathrm{C}$, and the time of $2 \mathrm{~h}$. Thus, with the temperature set to $100{ }^{\circ} \mathrm{C}$, and the collection time set within $2 \mathrm{~h}$, the increase in the exposed surface of the specimen where formaldehyde is emitted would increase the amount of formaldehyde emissions per hour, which would allow for fast collection and measurement.

First, to find the optimal collection time at the set temperature of $100{ }^{\circ} \mathrm{C}$ with the collection test device designed for the development of an accelerated collection method based on the exposed area, the study used MDF $4.5 \mathrm{~mm}$ and PB $18 \mathrm{~mm}$. Two specimens and four specimens with the exposed area of $163 \mathrm{~cm}^{2}$ were tested three times for 1 and $2 \mathrm{~h}$ each and the results were averaged and compared with those of the desiccator method. The results were shown in Figs. 7 to 10 .

As shown in Figs. 7 to 10, from the comparison between the emission values by grade based on the desiccator method and those from the collection test device set by this study, it was determined that the condition at which the similar emission intensity would result for a short time was two specimens with the exposed area of $163 \mathrm{~cm}^{2}$ for $1 \mathrm{~h}$. Thus, with two specimens at $100{ }^{\circ} \mathrm{C}$ for $1 \mathrm{~h}$, the formaldehyde emissions of MDF $15 \mathrm{~mm}$, MDF $18 \mathrm{~mm}$, and PB 18 $\mathrm{mm}$ by grade were measured by the collection test

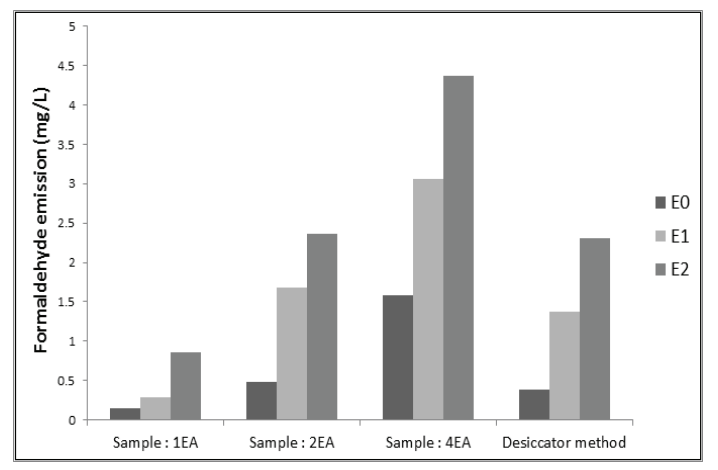

Fig. 7. Comparison of formaldehyde emission according to exposed area in accelerated collection method for $1 \mathrm{~h}$ from MDF (4.5 mm).

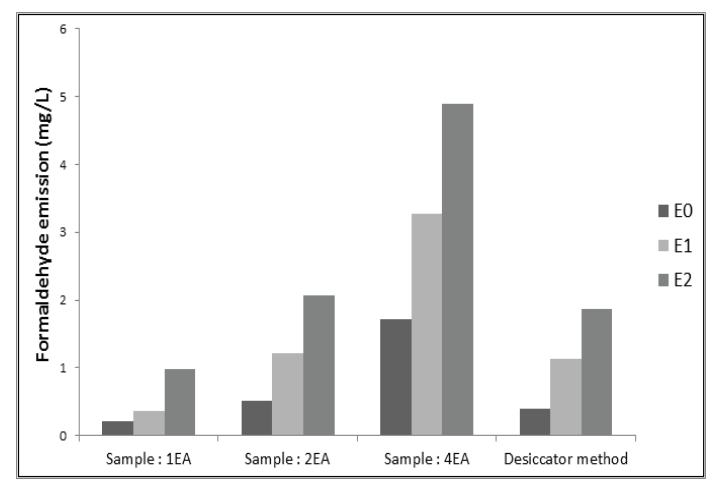

Fig. 8. Comparison of formaldehyde emission according to exposed area in accelerated collection method for $1 \mathrm{~h}$ from PB (18 mm). 


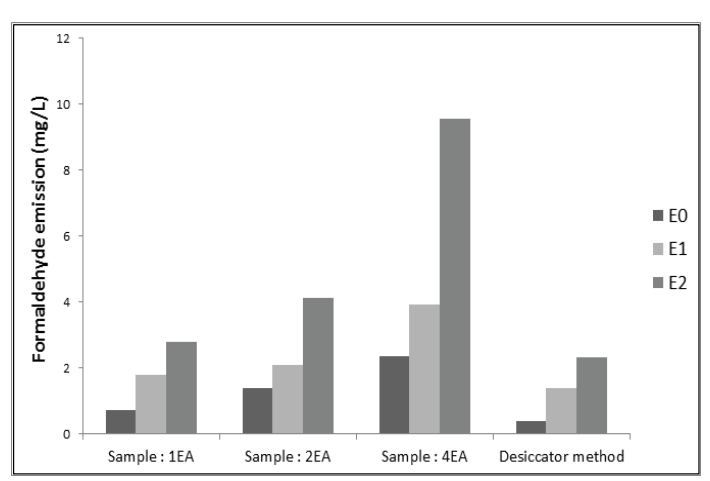

Fig. 9. Comparison of formaldehyde emission according to exposed area in accelerated collection method for $2 \mathrm{~h}$ from $\mathrm{MDF}$ (4.5 mm).

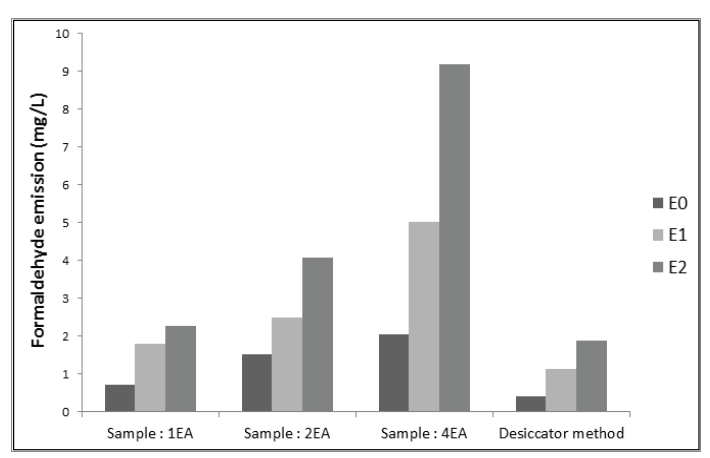

Fig. 10. Comparison of formaldehyde emission according to exposed area in accelerated collection method for $2 \mathrm{~h}$ from PB (18 $\mathrm{mm})$.

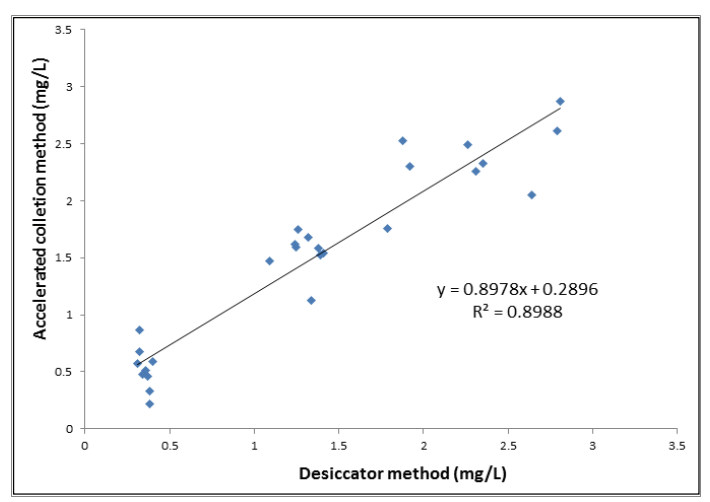

Fig. 11. Correlation of accelerated collection method of MDF $\left(163 \mathrm{~cm}^{2} \times 2\right)$ for $1 \mathrm{~h}$ withdesiccator method $\left(\mathrm{R}^{2}=0.8988\right)$.

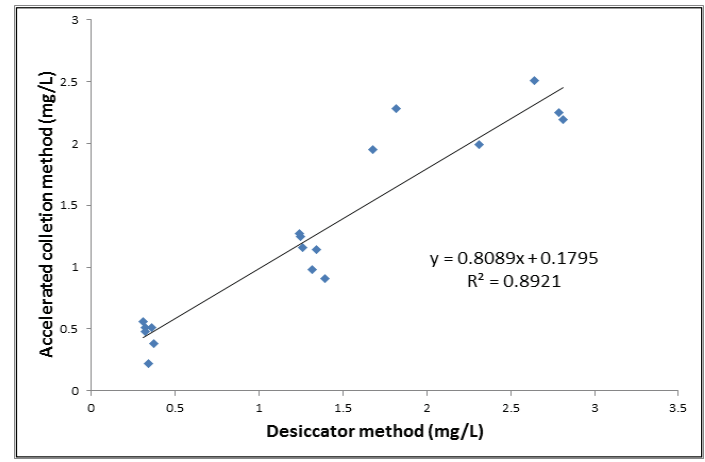

Fig. 12. Correlation of accelerated collection method of PB $\left(163 \mathrm{~cm}^{2} \times 2\right)$ for $1 \mathrm{~h}$ with desiccator method $\left(\mathrm{R}^{2}=0.8921\right)$.

device, the results of which were compared with those of the desiccator method to examine the correlation between the two results. It showed a high correlation with $\mathrm{r}^{2}=0.8988$ for MDF $\left(163 \mathrm{~cm}^{2} \times 2\right)$ and $\mathrm{r}^{2}=0.8921$ for $\mathrm{PB}\left(163 \mathrm{~cm}^{2} \times 2\right)$ (Figs. 11 and 12).

\subsubsection{Use of the accelerated collection method}

The overall formaldehyde emission results in the above collection process shows that the correlation between the formaldehyde emissions of the desiccator method and those of the developed method was relatively high when the exposed area was $163 \mathrm{~cm}^{2}$, the temperature was $100{ }^{\circ} \mathrm{C}$ and the time was $2 \mathrm{~h}$, as well as when there were two specimens with the exposed area at $163 \mathrm{~cm}^{2}\left(163 \mathrm{~cm}^{2} \times 2\right)$, at temperature of $100{ }^{\circ} \mathrm{C}$ and collection time of $1 \mathrm{~h}$. However, since the aim of this study was to rapidly measure formaldehyde, the two specimens with exposed area of $163 \mathrm{~cm}^{2}$ (163 $\left.\mathrm{cm}^{2} \times 2\right)$, temperature of $100{ }^{\circ} \mathrm{C}$ and collection time of $1 \mathrm{~h}$ were set to the standardized conditions.

Based on the standardized conditions set in this process, the study conducted a test with specimens unused in the actual test after commissioning Korea Conformity Laboratories (KCL) to conduct a test based on the desiccator method to evaluate the accelerated 


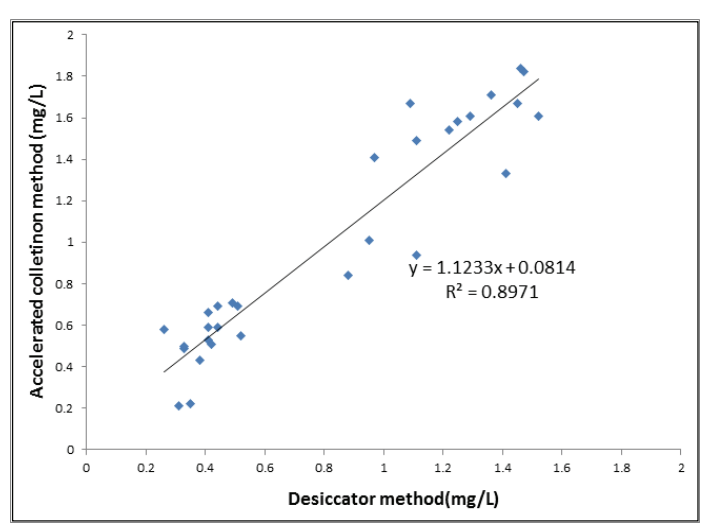

Fig. 13. Correlation of accelerated collection method with desiccator method $\left(\mathrm{R}^{2}=0.8971\right)$.

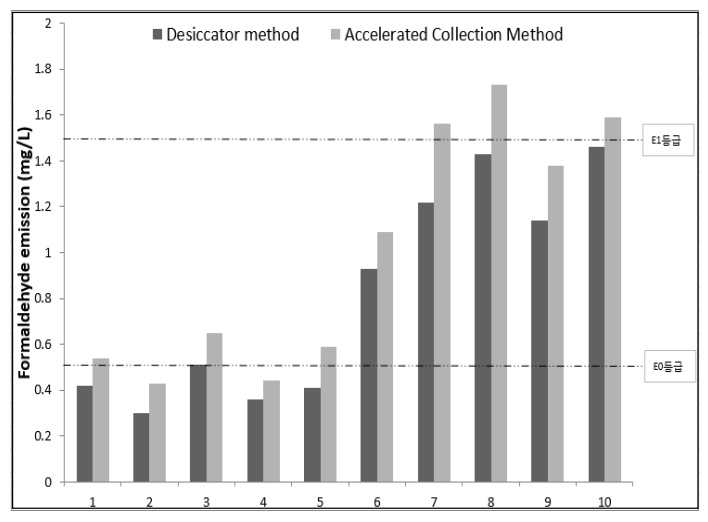

Fig. 14. Comparison of desiccator method and accelerated collection method for 10 materials.

collection method. The leftover specimens were cut to fit into the exposed area of $163 \mathrm{~cm}^{2}$, and the formaldehyde emissions were measured by the accelerated collection method three times per material for 10 different materials.

The formaldehyde emissions were measured with the collection test device at two specimens $\left(163 \mathrm{~cm}^{2} \times 2\right)$, at $100{ }^{\circ} \mathrm{C}$ for $1 \mathrm{~h}$, and the measured emission values were compared with those of the desiccator method to determine the correlation. To verify the applicability of the accelerated collection method, the formaldehyde emissions from the desiccator method were compared with those of the developed collection process, which showed a high correlation at $r^{2}=0.8971$ (Fig. 13).

However, when the average results of the three test sets on the desiccator and accelerated collection method were compared, the application of the accelerated collection method often showed somewhat higher results than those of the desiccator method (Fig. 14), and the emission results from the desiccator method corresponded to E0 grade, but sometimes, the accelerated collection method showed emission results corresponding to E1 grade. Furthermore, the formaldehyde emissions by the desiccator method corresponded to E1 grade, but the accelerated collection method sometimes showed E2 grade.

\section{CONCLUSION}

This study was conducted to develop an accelerated formaldehyde collection test process for swift and accurate measurement and evaluate the formaldehyde emissions based on the developed process. Toward this end, the study measured the formaldehyde emissions by the desiccator method and determined the optimal conditions, such as temperature, time, and exposed area, based on the accelerated collection method. The evaluation results of the developed process provided the following conclusions.

1. As for the optimal temperature and time under the accelerated collection method, the comparison of the formaldehyde emissions by the desiccator method by grade to those from the developed process showed that the formaldehyde emission intensity was relatively similar in the two methods when the temperature was $100{ }^{\circ} \mathrm{C}$ and the collection time was $2 \mathrm{~h}$. Therefore, the analysis of the correlation between the formaldehyde emissions by the desiccator method and those of the developed collection process showed a high correlation with $r^{2}=0.8936$ for MDF and $r^{2}=0.8872$ 
for PB.

2. Under the collection test conditions at $100{ }^{\circ} \mathrm{C}$ for $2 \mathrm{~h}$, set above, the emission values were measured with different exposure areas for faster measurement. The results were compared with those of the desiccator method, which showed that the two results were somewhat similar when two $163 \mathrm{~cm}^{2}$ specimens $\left(163 \mathrm{~cm}^{2} \times 2\right)$ were used at 100 ${ }^{\circ} \mathrm{C}$ for $1 \mathrm{~h}$, and thus, the formaldehyde emissions by the desiccator method were compared to those from the developed collection process with the two $163 \mathrm{~cm}^{2}$ specimens $\left(163 \mathrm{~cm}^{2} \times 2\right)$ at $100{ }^{\circ} \mathrm{C}$ for $1 \mathrm{~h}$, and the correlation between the two emissions was analyzed. The result showed a high correlation with $\mathrm{r}^{2}=0.8988$ for $\operatorname{MDF}\left(163 \mathrm{~cm}^{2} \times 2\right)$ and $\mathrm{r}^{2}=0.8921$ for PB $\left(163 \mathrm{~cm}^{2} \times 2\right)$.

3. As shown in the above results, the conditions at which the fastest and most accurate formaldehyde emission measurement under the accelerated collection method were two $163 \mathrm{~cm}^{2}$ specimens $\left(163 \mathrm{~cm}^{2} \times 2\right)$ at $100{ }^{\circ} \mathrm{C}$ for $1 \mathrm{~h}$, and to verify the applicability of the accelerated collection method, the specimens left after the commissioned test of the desiccator method by the KCL were used to conduct a test based on the standardized accelerated collection method, the result of which was then compared with the result of the desiccator method. The results showed a relatively high correlation at $\mathrm{r}^{2}=0.8971$.

4. However, when the average values of the test results from the desiccator method and the accelerated collection method were compared, the accelerated collection method, in most cases, showed somewhat higher results than the desiccator method. Compared to the emission results of the desiccator method, the results of the accelerated collection method were often one grade higher.
5. It was determined that since the formaldehyde emission grade from the accelerated collection method was one grade higher, the developed process could be sufficiently applied to manufacturing plants from the perspective of quality control. If the developed process is set to E0 grade for quality control, the results from the desiccator method would show SE0 emissions, which is higher in quality than E0 grade, and if it is set to E1 grade, the lowest emission scope, for quality control, E0 grade level control would be possible. Therefore, the implementation of the developed process to manufacturing sites would be able to replace the desiccator method, which would take $24 \mathrm{~h}$ for testing, and thus, would enable the measurement of formaldehyde emission for only $1 \mathrm{~h}$, leading to faster quality control.

\section{REFERENCES}

Jang, J.H., Lee, M., Lee, S.M., Park S.B. 2017. Formaldehyde Emission of Building Materials and Effect of Carbonized Board on Their Reduction. Journal of the Korean Wood Science and Technology 45(3): 327-334.

Jang, J.H., Lee, M., Kang, E.C., Lee, S.M. 2017. Characteristics of Low Density Fiberboards Bonded with Different Adhesives for Thermal Insulation (II)-Formaldehyde • Total Volatile Organic Compounds Emission Properties and Combustion Shapes. Journal of the Korean Wood Science and Technology 45(5): 580-587.

Kim J.I. 2012. Development of raipd detection method for volatilized formaldehyde from wood and feed, Kangwon National University, Master thesis.

Korea trade commission in Ministry of Trade, Industry and Energy. 2016. Survey on the competitiveness of the furniture industry.

KS F 3104. 2016. Particle board. Korean Agency for 
Technology and Standards.

KS F 3200. 2016. Fiber board. Korean Agency for Technology and Standards.

KS M 1998. 2017. Determination of the emission rate of formaldehyde and volatile organic compounds in building interior products. Korean Agency for Technology and Standards.

Lee, Y.K., Kim, H.J. 2005. The effects of temperature and bake-out on formaldehyde emission from wood composites of urea-formaldehyde resin, Indoor Air 10(2): 1850-1853.

Lee, Y.K., Kim, H.J. 2012. Effects of Temperature and Bake-out on Formaldehyde Emission from UF Bonded Wood Composites. Journal of the Korean Wood Science and Technology 40(2): 91-100.
Meyer, B., Hermanns, K. 1985. Formaldehyde release from pressed wood products. Advances in Chemistry 21(0): 101-116.

Nelson, N., Levine, R.J., Albert, R.E., Blair, A.E., Griesemer, R.A., Landrigan, P.J., Stayner, L.T., Swenberg, J.A. 1986. Contribution of formaldehyde to respiratory cancer. Environmental Health Perspectives 70: 23-35.

Park, J.Y., Park, S.B., Park, B.D., Moon, S.P. 2005. Indoor Air Environment Wood-based panels, National Institute of Forest Science.

Park, J.N. 2006. Study on the characteristics of formaldehyde emission from wood-based panel treated with several surface finishing materials. Chunnam National University, Master thesis. 


\title{
APPENDIX
}

\author{
(Korean Version)
}

\section{가속 포집방법을 이용한 목질보드류의 폼알데하이드 방출량 평가}

초록 : 본 연구는 목질보드류 및 가구 생산 현장에서 주로 품질 관리를 위해 사용되는 데시케이터 방법을 개선 및 보완함으로써 측정 및 포집 시간을 단축하는 가속 포집 공정을 개발하기 위해 수행되었다. 먼저 등급별 목질 보드류에 대해 데시케이터 방법에 의한 포름알데히드를 측정하였다. 이어 개발된 공정을 가지고 데시케이터 방법과 비교하였을 때 최적 온도와 시간, 노출면적 등을 선정하여 시험한 후 그 상관성을 분석하였다. 그 결과 온도는 $100{ }^{\circ} \mathrm{C}$, 시간은 1 시간, 시편은 2 개일 때 데시케이터 방법과 비교적 유사한 결과값을 나타내었으며 그 상관성도 높은 것으로 나타났다. 개발된 시험 공정을 검증하기 위해서 설정된 표준화된 온도 및 시간, 시편의 매수를 가지고 Korea Conformity Laboratories (KCL)에 의뢰되어 실제 시험에 쓰이지 않았던 시료를 가지고 비교하였다. 그 결과 데시케이터 방법과의 상관성은 매우 높은 것으로 나타났다. 그러나 가속 포집 공정에서의 포름알데히드 방출량 결과값은 데시케이터 방법보다 대부분 높게 나타났다. 몇 개 시료의 포름알데히드 방출 등급은 한단계 더 높게 나타나는 경우도 있었다. 하지만 품질관리의 관점에서는 본 연구에서 설계된 가속 포집 공정 방법에 의해 충분히 적용될 수 있다고 판단되었다.

\section{1. 서 론}

국민들의 삶의 질이 향상됨에 따라 DIY가구, 인테리어 리모델링 등 주거 환경에 대한 관심이 증가 하였다. 이에 따라, 최근 가구 시장은 지속적으로 성장하고 있으며, 이에 가구의 원재료인 섬유판(Medium density fiberboard; 이하 MDF)과 파티클 보드(Particle board, 이하 PB) 사용량 또한 증가하고 있다. 글로벌 가구업체인 이케아(IKEA)의 2014년 국내 진출 이후 가구산업 의 전체적인 성장과 더불어 1 2인 가구의 증가 및 건축물 리모델링 시장 확대, 파레트용 사용 증가 등으로 인해 파티클보드 및 섬유판의 전체적인 생산, 수입, 수요가 증가하게 되었다(Korea trade commission in Ministry of Trade, 2016).

이러한 $\mathrm{MDF}$ 와 $\mathrm{PB}$ 의 제조 과정을 보면 폐목재나 목재 원료들을 파티클이나 섬유로 제조 한 후 접착제를 도포해 건조 및 성형과정을 거쳐 열압 제조 한다. 이때 사용하는 접착제는 요소-폼알데하이드 수지와 요소.멜라민-폼알데하이드 수지 등 아미노 계 수지 접착제인데 보드의 구성 원료인 칩이나 섬유들 간의 결합을 유도하여 보드를 형성하게 된다(Meyer et al, 1985). 접착제 의 주원료 중 하나인 폼알데하이드는 WHO에서는 1 급 발암물질로 규제하고 있으며, 이 밖에 여러 국가에서 방출량 및 1 일 흡입량 등을 규제하고 있는 유해물질이다. 이러한 폼알데하이드의 노출에 따른 인체에 미치는 영향을 보면 인체에 대한 독성이 매우 강하여 단기간 노출이 되면 호흡기와 점막을 심하게 자극하고 어지러움 증과 두통을 발생시키며, 장기간 노출이 될 경우 비염이나 천식, 기관지염 등 호흡기 질환과 알레르기성 접촉성 피부염, 암 등을 유발시키는 것으로 알려져 있다(Nelson, 1986).

이에 폼알데하이드는 국내에서도 2004년부터 환경부 실내공기질 관리법 재정과 더불어 국민들의 관심과 함께 범정부적 관리가 진행되고 있다. 실내공기질 관리법에서는 가구, 실내 바닥재, 마감재 등 실생활에서 사용되는 모든 제품들에 대하여 규제를 하고 있다(Jang et al., 2017). 또한, 한국산업표준에서도 2016년도 개정을 통해 실내에 사용되는 목질재료는 최대 E0 이하 수준으로 규제를 하고 있으며 전 세계적으로도 목질보드류에 대한 폼알데하이드 방출 환경 규정을 마련하여 시행해오고 있다. 나라마다 폼알데하이드 방출량을 측정하는 방법과 기준 방출량 들이 조금은 차이가 있지만 환경규제가 강화될수록 기준이 엄격해지고 있다(Park et al., 2005).

이처럼 우리나라뿐만 아니라 전 세계적으로 실내에서 방출되는 폼알데하이드에 대한 위험성을 인지하고 폼알데하이드 방출 에 대하여 규제를 지속적으로 강화하고 있다. 폼알데하이드 방출량은 국내에서 주로 사용되고 있는 데시케이터법이나 소형챔버 법 뿐만 아니라, 퍼포레이터법, 가스 분석법 등으로 다양한 방법으로 측정이 가능하다. 국내에서 가장 오랫동안 표준화 되어있고 사용되어진 데시케이터법은 가장 간편하면서 시험 비용이 적게 들며 시험하기 쉽기 때문에 생산 공장에서 품질관리를 위하여 주로 사용하는 방법이다. 반면 단점으로는 $\mathrm{HCHO}$ 외 VOCs에 대한 측정이 불가능한 단점이 있다. 소형챔버법의 경우 실제의 거주 공간 상태에 가까운 일정한 환기량 아래서 측정을 실시 할 수 있고 $\mathrm{HCHO}$ 뿐만 아니라 VOCs에 대한 측정이 가능한 장점이 있는 반면에 시험기간이 오래 걸리고 표면 방출량에 대한 측정이므로 4면이 노출이 되는 데시케이터 방법에 비해 폼알데하이드 방출에 대해 저평가 되며 분석 장비나 분석 기법에 고도화된 전문적인 기술이 필요할 뿐만 아니라 분석 장비나 분석 장치(HPLC, GC/MS 등)가 비싸다는 단점이 있다. 앞서 언급했던 것처럼 국내의 경우 대부분이 데시케이터법이나 소형챔버 
법으로 표준화되어 있고 각종 인증 및 규제에 사용되어지고 있다.

2013년 목재의 지속가능한 이용에 관한 법률 제정 이후 목질보드에 대한 품질 관리는 목재제품의 규격과 품질기준에 따라 의무적으로 데시케이터법에 의해 이루어지고 있다. 또한 실내 공기 환경에 대한 지속적인 관심 및 위험 요인에 대한 연구 분석 결과에 따라 환경부에서는 가구류나 바닥재 등 환경마크인증을 위한 기준 규격서에는 소형챔버법이나 데시케이터법 두 가지 방법 중에 한 가지를 선택해서 인증을 내어주고 있으며 산업통상자원부에서 관리하는 가구류 공급자적합성확인기준 (KC)에서도 소형챔버법이나 데시케이터법을 공급업체나 수입업체가 방법을 선택해서 직접 관리하게 끔 하고 있다.

이에 목질보드를 생산하거나 사용하는 업계에서는 소형챔버법의 경우 분석 장치나 장비가 고가 이고 전문화된 인력 부족과 공간적 제약으로 인해 현장에서는 대부분이 간편하고 쉽게 시험할 수 있는 데시케이터 방법으로 품질관리를 하고 있다. 하지만 이 데시케이터 방법은 다른 폼알데하이드 방출 시험 방법에 비해서는 빠른 시간 내에 방출 시험을 할 수 있지만 24시간의 포집시간이 필요해 생산 현장에서는 즉각적인 품질 관리는 어려운 실정이다. 이에 생산 현장에서는 분석 기법이 간편하고, 빠른 시간 내에 폼알데하이드 방출 농도를 파악하여 즉각적인 품질 관리를 할 수 있는 방법이 필요하다.

이에, 본 연구에서는 목질 보드류 및 가구 생산 현장에서 주로 품질관리를 위해 사용하는 데시케이터법을 수정 및 보완하여 측정 및 포집 시간을 줄인 가속 포집 공정을 개발하고 가속 포집 공정 적용에 따른 방출량에 대한 평가를 하고자 하였다. 이를 위해 데시케이터법의 장점인 분석 방법의 용이함과 소형챔버법의 장점인 실제의 거주 공간 상태에 가까운 일정한 환기량을 가하여 측정하는 장점들을 바탕으로 신속하고 정확한 측정이 가능한 폼알데하이드 가속 포집 공정을 개발하고, 데시케이터 방법과 가속 포집 공정 방법 간의 폼알데하이드 방출 등급별 특성 비교를 통해 목질 보드 및 가구 생산 현장에서 실제 사용 가능성에 대한 검증을 하고자 한다.

\section{2. 재료 및 방법}

\section{1. 공시 재료}

실험에 사용한 MDF는 가구용재 및 인테리어 용재로 주로 사용되어지는 두께 $4.5 \mathrm{~mm}, 15 \mathrm{~mm}, 18 \mathrm{~mm}$ 를 실험에 사용하였으 며, $\mathrm{PB}$ 는 $15 \mathrm{~mm}, 18 \mathrm{~mm}$ 를 사용하였다. MDF는 인천에 위치한 $\mathrm{A}$ 社로부터 분양받았으며, $\mathrm{PB}$ 는 인천에 위치한 $\mathrm{B}$ 社로부터 분양받았다. 사용한 재료의 특성은 파티클보드(KS F 3104, 2016), 섬유판(KS F 3200, 2016) 방법에 따라 밀도 및 함수율에 대한 실험을 하였으며 그 결과는 Table 1 과 같다.

\section{2. 폼알데하이드 가속 포집 공정 설계}

목질보드에서 방출되는 폼알데하이드를 신속하고 정확하게 포집하기 위해서 공기주입부와 휘발부, 포집부로 크게 3 구역으로 나누어 설정하였다. 공기주입부는 Air Compressor로 생성된 공기가 12 개의 공기주입관으로 나갈 수 있게 연결이 되어 있으며 유속을 조절할 수 있는 조절 밸브가 달려있다. 휘발부는 온도가 조절되는 INCUBATOR안에 열의 흡수가 높은 투명한 유리 용기를 사용하였으며 유리병과 유리병 덮개 사이의 폼알데하이드 유출을 막기 위해 고무링을 설치하였다. 또한 유입되는 공기를 휘발부 유리병 내의 시료가 막지 못하게 시료 받침판을 두어 공기의 흐름이 원활히 이루어질 수 있도록 설치하였다. 포집부는 설치된 연결관을 통하여 유출 되는 공기의 유속을 측정하기 위해 디지털 유속 측정기를 배치하였으며 DURAN社의 GL45 제품을 사용하여 포집부의 유리병과 폴리우레탄관의 연결을 위한 장치를 설치하였다. 목질보드의 공기 유입 및 휘발, 포집 과정을 요약한 모식도를 Fig. 1에 나타내었고 실제 시험한 사진은 Fig. 2와 같다.

\section{3. 데시케이터 방법에 의한 폼알데하이드 방출량}

실험에 사용된 목질보드의 폼알데하이드 방출량을 파악하기 위하여 폼알데하이드 방출 시험법(KS M 1998, 2017)의 기준으 로 시험을 진행하였다. 각 보드의 표면적 $1,800 \mathrm{~cm}$ 에 준한 시편 매수를 결정하고, 시편들의 무게 변화율이 $0.1 \%$ 이하에 도달할 때 까지 온도 $(20 \pm 2)^{\circ} \mathrm{C}$, 상대습도 $(65 \pm 5) \%$ R.H.에서 7일 동안 전처리 과정을 진행하였다. 전처리과정이 끝난 시편들을 데시케이터에 흡수액인 증류수 $300 \mathrm{~mL}$ 를 넣고 설치하여 항온항습기에 넣고 온도 $(20 \pm 1)^{\circ} \mathrm{C}$ 에서 24시간 동안 포집하였다. 폼알데하이드가 흡수된 증류수를 아세틸아세톤법으로 발색시켜 $412 \mathrm{~nm}$ 의 파장에서 분광광도계로 측정하였다.

\section{4. 가속 포집 시험 공정 개발}

2.4.1. 적정 온도 및 시간 선정

실험에 사용된 목질 보드류의 가속포집공정 적용 방법에 따라서 설계된 포집 시험 장치를 이용하여 시험하였다. 가속포집공정 
적용 시 시편의 크기와 시험을 위한 조건은 다음과 같다.

데시케이터 방법 시에는 데시케이터 크기가 $11 \mathrm{~L}$ 이고 표면적 $1,800 \mathrm{~cm}$ 에 준하여 $5 \mathrm{~cm} \times 15 \mathrm{~cm}$ 크기의 시편의 매수를 설정하는 데 가속포집공정 적용 방법에 따라 설계된 시험 장치에서는 휘발부의 유리병의 크기가 $1,000 \mathrm{~mL}$ 인 점을 고려하여 휘발부 유리병 내에서의 시료 표면적의 크기도 $1 / 11$ 로 줄여 가로 $5 \mathrm{~cm} \times 15 \mathrm{~cm}$ 크기의 시편을 가지고 노출 표면적을 $163 \mathrm{~cm}$ 로 맞추어 설정하였다.

이어서 가속포집공정법의 시험 조건은 다음과 같다. Park (2004), Lee and Kim (2012)에 의하면 데시케이터 방법에 의한 폼알데하이드 방출 시험 시 측정 온도가 증가할수록 폼알데하이드 방출량이 증가하는 것으로 나타났다. 또한 Kim (2012)에 의하면 목재 및 사료 중에 섞여 있는 폼알데하이드를 신속 검출하기 위한 방법으로 휘발부와 포집부가 분리된 장치에서 휘발 온도 및 질소 유량별 폼알데하이드 포집률을 측정한 결과 질소 유량은 $40 \mathrm{cc} / \mathrm{min}, 100{ }^{\circ} \mathrm{C}$ 조건에서 30 분간 포집 할 경우 $94.8 \%$ 의 최대 포집률을 확인 하였다.

이에 앞선 선행 연구를 바탕으로 본 연구의 최종 목적인 측정 및 포집 시간을 줄인 가속 포집 공정을 개발하기 위한 시험 조건은 기류의 량은 $40 \mathrm{cc} / \mathrm{min}$ 으로 고정 설정하고, 폼알데하이드 방출을 위한 온도는 $100{ }^{\circ} \mathrm{C}, 60{ }^{\circ} \mathrm{C}, 25{ }^{\circ} \mathrm{C}$ 설정하여 온도 및 시간에 따른 가속포집공정 적용법과 데시케이터 방법과의 폼알데하이드 방출 특성을 비교하였다.

\subsection{2. 시료의 노출 면적의 영향}

데시케이터법 또는 소형챔버법에 의한 폼알데하이드 방출 시험 시 목질 보드의 시료 표면적 및 시간에 따라 폼알데하이드 방출량은 달라질 수 있다. 데시케이터방법에 의한 폼알데하이드 방출 시험 시에는 시료의 노출 면적을 $1,800 \mathrm{~cm}^{2}$ 으로 설정하고, 24시간 동안 폼알데하이드의 포집이 되도록 표준화되어 있으며 소형챔버법에 의한 폼알데하이드 및 VOC 시험 시에는 휘발된 폼알데하이드 방출량에 대해 표준화된 값을 나타내기 위해 방출량 값 결과 표시 시 시간에 따른 단위 면적당 방출량 $\left(\mathrm{g} / \mathrm{m}^{2} \cdot \mathrm{h}\right)$ 으로 방출량 값을 산출하고 있다. 따라서 본 연구에서 진행하는 가속 포집 공정에서도 표준화된 시편의 노출면적과 적정 포집 시간을 찾을 필요가 있다고 판단되었다.

이에 본 시험에서는 포집 및 휘발 공정의 효율을 높이기 위해 앞서 설정한 온도 및 시간에 따른 폼알데하이드 방출 특성 시험 시 설정한 노출 면적 $163 \mathrm{~cm}$ 의 시편을 2개(163 $\left.\mathrm{cm}^{2} \times 2\right), 4$ 개(163 $\left.\mathrm{cm}^{2} \times 4\right)$ 로 설계된 포집 공정에서 휘발부의 시료가 노출되는 표면적을 늘려 포집 및 휘발 공정 시간을 단축시키고자 하였다. 가속포집공정 적용 방법에 따라서 설계된 포집 시험 장치를 이용하여 노출 면적에 따른 폼알데하이드 방출 특성을 데시케이터법과 비교하였다.

\section{3. 결과 및 고찰}

\section{1. 데시케이터법에 의한 폼알데하이드 방출량}

데시케이터에서 $\mathrm{MDF} 4.5 \mathrm{~mm}, \mathrm{MDF} 12 \mathrm{~mm}, \mathrm{MDF} 18 \mathrm{~mm}, \mathrm{~PB} 15 \mathrm{~mm}, \mathrm{~PB} 18 \mathrm{~mm}$ 등 5가지의 목질보드를 폼알데하이드 방출 등급별로 폼알데하이드 방출량을 3 회씩 측정하였다. 등급에 따른 각 재료 및 두께별 폼알데하이드의 방출 농도 측정 결과는 Fig. 3 과 같이 나타내었다.

\section{2. 가속 포집 시험 공정의 개발}

3.2.1. 적정 온도 및 시간 선정

먼저 온도 조건 $25^{\circ} \mathrm{C}, 60{ }^{\circ} \mathrm{C}$ 에서 $\mathrm{MDF} 4.5 \mathrm{~mm}$ 와 $\mathrm{PB} 15 \mathrm{~mm}$ 를 가지고 가속포집공정 개발을 위해 설계된 포집 시험 장치에서 등급별 폼알데하이드 방출 농도를 3 반복 후 평균하였다. $25{ }^{\circ} \mathrm{C}$ 에서 1 시간, 2 시간, 3 시간에 가속 포집 시험 장치에 의한 폼알데하 이드 방출량은 $\mathrm{MDF} 4.5 \mathrm{~mm}, \mathrm{~PB} 15 \mathrm{~mm}$ 모두 E2등급, $\mathrm{E} 1$ 등급, $\mathrm{E} 0$ 등급에서 불검출(검출한계 $0.05 \mathrm{mg} / \mathrm{L}$ )로 나타났다. 60 ${ }^{\circ} \mathrm{C}$ 에서 1 시간, 2 시간, 3 시간에 각각 가속 포집 시험 장치에 의한 폼알데하이드 방출량은 1 시간과 2 시간 일 때는 $25{ }^{\circ} \mathrm{C}$ 일 때와 마찬가지로 $\mathrm{MDF} 4.5 \mathrm{~mm}, \mathrm{~PB} 15 \mathrm{~mm}$ 모두 불검출이었으나, $60{ }^{\circ} \mathrm{C}$ 에서는 $\mathrm{E} 1$ 등급, $\mathrm{E} 0$ 등급은 불검출이였고 $\mathrm{E} 2$ 등급에서 $\mathrm{MDF}$ 는 $0.08 \mathrm{mg} / \mathrm{L}$ 였고 $\mathrm{PB}$ 는 $0.09 \mathrm{mg} / \mathrm{L}$ 로 방출량이 측정되었다.

앞선 $25{ }^{\circ} \mathrm{C}$ 와, $60{ }^{\circ} \mathrm{C}$ 에서의 포집 시험 장치에 의한 폼알데하이드 방출 결과를 보았을 때, 본 포집 공정에서는 $60{ }^{\circ} \mathrm{C}, 3$ 시간 이상은 되어야 폼알데하이드 방출량을 측정 할 수 있다는 것을 확인 할 수 있었다.

Lee Y.K., Kim H.J. (2005)의 연구에 따르면 데시케이터 방법에 의해 시간 및 온도에 따른 목질 보드의 폼알데하이드 방출 특성에 관한 연구 결과 폼알데하이드 방출량은 시간에 따라 지속적으로 증가하며 온도가 높아질수록 6 시간에서 12 시간 내에서 방출량 변화의 폭은 횔씬 커진 다는 것을 실험을 통해 밝혀내었다. 
이와 같은 점으로 미루어 볼 때 본 포집 공정에서의 주된 목적인 신속한 폼알데하이드 측정을 위해서는 앞서 실험했던 조건 보다 높은 온도인 $100{ }^{\circ} \mathrm{C}$ 가 되어야 휘발되는 폼알데하이드의 방출 속도가 증가하여 휘발되는 폼알데하이드를 신속히 포집 할 수 있을 것이라 판단하였다.

$100{ }^{\circ}$ 에서의 적정 포집 시험 시간을 찾기 위해 먼저 $\mathrm{MDF} 4.5 \mathrm{~mm}$ 를 가지고 1 시간, 2 시간, 3 시간, 6 시간 12 시간에 걸쳐 3 회씩 반복하여 시험을 진행하였으며 그 결과를 평균하여 Fig. 4 에 나타내었다. Fig. 4 에서 보듯이 $100{ }^{\circ} \mathrm{C}$ 에서는 포집 시험 장치에 의한 폼알데하이드 방출량 값이 각 등급별로 시간에 따라 늘어나는 것을 확인 할 수 있었다. 데시케이터 방법에 의한 등급별 방출량 값과 본 연구에서 설정한 포집 시험 장치에 의한 결과를 비교하였을 때 유사한 방출 강도를 내는 시간은 본 포집 공정에서 2시간 동안 포집이 이루어 졌을 때라고 판단되었다. 이에 $100{ }^{\circ} \mathrm{C}, 2$ 시간일 때 $\mathrm{MDF} 15 \mathrm{~mm}, \mathrm{MDF} 18 \mathrm{~mm}$ 와 PB $15 \mathrm{~mm}$, PB $18 \mathrm{~mm}$ 의 폼알데하이드 방출 등급별로 포집 시험 장치에 의한 방출량들을 추가적으로 측정하였으며, 측정한 방출량 값들과 데시케이터법에 의한 방출량간의 상관관계를 조사하였다. 데시케이터법에 의한 폼알데하이드 방출량과 본 연구 에서 개발된 포집 공정에 따른 폼알데하이드 방출량과 비교하였을 때 $\mathrm{MDF}$ 의 경우 $\mathrm{r}^{2}=0.8936, \mathrm{~PB}$ 의 경우 $\mathrm{r}^{2}=0.8872$ 로 높은 상관관계를 보였다(Fig. 5, Fig. 6).

\subsection{2. 시료의 노출 면적의 영향}

앞서 본 포집 공정에서의 온도 및 시간에 따른 폼알데하이드 방출 결과를 보았을 때, 노출 면적은 $163 \mathrm{~cm}^{2}$, 온도는 $100{ }^{\circ} \mathrm{C}$, 시간은 2 시간 일 때 데시케이터방법에 의한 폼알데하이드 방출량과 유사한 방출 강도를 나타내는 것을 확인 할 수 있었다. 이에 온도 조건은 $100{ }^{\circ} \mathrm{C}$ 로 고정하고 포집 시간은 2 시간 이내일 때 폼알데하이드가 방출 되는 시료의 노출 면적이 늘어나게 되면 시간당 폼알데하이드 방출량이 늘어나 신속히 포집 및 측정이 가능할 것이라 판단되었다.

먼저 고정된 온도 조건 $100{ }^{\circ} \mathrm{C}$ 에서 가속포집공정 개발을 위해 설계된 포집 시험 장치로 노출 면적에 따른 적정 포집 시간을 찾기 위해 $\mathrm{MDF} 4.5 \mathrm{~mm}$ 와 $\mathrm{PB} 18 \mathrm{~mm}$ 를 가지고 진행 하였다. 노출 면적 $163 \mathrm{~cm}^{2}$ 의 시편을 2개, 4 개를 1 시간 및 2시간으로 각각 3 반복 후 평균하였으며 데시케이터 방법에 의한 결과 값과 비교하여 Figs. 7 10에 나타내었다.

Figs. 7 10의 결과에서 보듯이 데시케이터 방법에 의한 등급별 방출량 값과 본 연구에서 설정한 포집 시험 장치에 의한 등급별 노출면적에 따른 폼알데하이드 방출 결과를 비교하였을 때 빠른 시간 내에 유사한 방출 강도를 내는 조건은 노출 면적 $163 \mathrm{~cm}^{2}$ 의 시편이 2 개와 1 시간 동안 포집이 이루어 졌을 때라고 판단되었다. 이에 시편이 2 개이고, $100{ }^{\circ} \mathrm{C}, 1$ 시간일 때 $\mathrm{MDF} 15 \mathrm{~mm}, \mathrm{MDF} 18 \mathrm{~mm}$ 와 PB $18 \mathrm{~mm}$ 의 폼알데하이드 방출 등급별로 포집 시험 장치에 의한 방출량들을 측정하였으며, 측정한 방출량 값들과 데시케이터법에 의한 방출량간의 상관관계를 조사하였다. 데시케이터법에 의한 폼알데하이드 방출량과 본 연구에서 개발된 포집 공정에 따른 폼알데하이드 방출량과 비교하였을 때 $\mathrm{MDF}\left(163 \mathrm{~cm}^{2} \times 2\right)$ 의 경우 $\mathrm{r}^{2}=0.8988, \mathrm{~PB}(163$ $\left.\mathrm{cm}^{2} \times 2\right)$ 의 경우 $\mathrm{r}^{2}=0.8921$ 로 높은 상관관계를 보였다(Fig 11, Fig 12).

\subsection{3. 가속 포집 시험 공정의 활용}

앞서 본 포집 공정에서의 전체적인 폼알데하이드 방출 결과를 보았을 때, 노출 면적은 $163 \mathrm{~cm}^{2}$, 온도는 $100{ }^{\circ} \mathrm{C}$, 시간은 2 시간 일 때와 노출 면적의 $163 \mathrm{~cm}^{2}$ 시편을 2개(163 $\left.\mathrm{cm}^{\prime} \times 2\right)$, 온도는 $100{ }^{\circ} \mathrm{C}$, 시간은 1 시간 일 때 데시케이터방법에 의한 폼알데하이드 방출량과 상관성이 비교적 높은 것으로 판단되었다. 하지만 본 연구의 목적이 폼알데하이드를 신속하게 측정하기 위함이므로 노출 면적의 $163 \mathrm{~cm}^{2}$ 시편은 2 개(163 $\left.\mathrm{cm}^{2} \times 2\right)$, 온도는 $100{ }^{\circ} \mathrm{C}$, 포집시간은 1 시간으로 본 공정의 표준화된 조건을 설정하였다.

본 공정에서 설정된 표준화된 조건을 바탕으로 한국건설생활환경시험연구원에 데시케이터 방법으로 시험 의뢰되고 난 후 실제 시험에 쓰이지 않았던 남은 시편들을 가지고 가속 포집 시험 공정의 검증 차원에서 비교하고자 시험을 진행하였다. 남은 시편들은 노출면적을 $163 \mathrm{~cm}$ 에 맞추어 재단하였으며 10 가지의 다른 재료를 가지고 한 재료 당 3 회씩 가속 포집 공정에서의 폼알데하이드 방출량을 측정하였다.

시편이 2 개(163 cm×2)이고, $100^{\circ} \mathrm{C}, 1$ 시간일 때 포집 시험 장치에 의한 폼알데하이드 방출량들을 측정하였으며, 측정한 방출량 값들과 데시케이터법에 의한 방출량간의 상관관계를 조사하였다. 가속 포집 시험 공정의 활용성에 대한 검증 차원에서 데시케이 터법에 의한 폼알데하이드 방출량과 본 연구에서 개발된 포집 공정에 따른 폼알데하이드 방출량과 비교하였을 때 $\mathrm{r}^{2}=0.8971$ 로 높은 상관관계를 보였다(Fig. 13).

하지만 데시케이터 방법과 가속 포집 시험 공정에 의한 방법에 대해 3세트 시험한 결과의 평균값을 비교하였을 때에는 대부분 가속 포집 공정방법 적용 시에 데시케이터 방법보다 다소 높은 결과 값을 나타냈으며(Fig. 14), 데시케이터 방법에 의한 방출량 결과는 $\mathrm{E} 0$ 등급에 해당되었지만 가속 포집 공정에서는 $\mathrm{E} 1$ 등급에 해당되는 방출량 값이 나오는 경우도 있었다. 


\section{Hyun-jo Han $\cdot$ Seog-eon Lee $\cdot$ Seung-min Yang $\cdot$ Chul Choi $\cdot$ Seog-goo Kang}

또한 데시케이터 방법에 의한 폼알데하이드 방출량은 E1등급에 해당되지만 가속 포집 공정에서는 E2등급에 해당되는 방출량 값을 보이는 경우도 있었다.

\section{4. 결 론}

본 연구에서는 신속하고 정확한 측정이 가능한 폼알데하이드 가속 포집 시험 공정을 개발하고 개발된 공정 방법 적용에 따른 폼알데하이드 방출량을 평가하기 위해 실시되었다. 연구를 진행하기 위하여 데시케이터 방법에 의한 폼알데하이드 방출량 을 측정하였으며 가속 포집 시험 공정에 의한 적정 온도 및 시간, 노출면적에 관한 최적 조건을 찾고 개발된 시험 공정의 검증을 위한 시험 결과 다음과 같은 결론을 얻었다.

1. 가속 포집 시험 공정에서의 적정 온도 및 시간에 대한 결과 본 공정에서는 데시케이터 방법에 의한 등급별 폼알데하이드방 출량 결과와 비교하였을 때 $100{ }^{\circ} \mathrm{C}, 2$ 시간 동안 포집하였을 때 비교적 폼알데하이드 방출 강도가 비슷한 결과를 나타내었다. 이에 데시케이터법에 의한 폼알데하이드 방출량과 개발된 포집 공정에 따른 폼알데하이드 방출량 간의 상관성을 조사 하였을 때 $\mathrm{MDF}$ 의 경우 $\mathrm{r}^{2}=0.8936, \mathrm{~PB}$ 의 경우 $\mathrm{r}^{2}=0.8872$ 로 높은 상관관계를 보였다.

2. 앞서 설정 된 $100{ }^{\circ} \mathrm{C}, 2$ 시간 동안의 포집 시험 조건에서 더 신속한 측정을 위해 노출 면적을 달리 하여 방출량 값을 측정하였다. 그 결과 데시케이터 방법에 의한 폼알데하이드 결과와 비교하였을 때 $163 \mathrm{~cm}^{2}$ 시편 2 개 $(163 \mathrm{~cm} \times 2)$ 를 가지고 $100^{\circ} \mathrm{C}$, 1 시간 동안 포집하였을 때 데시케이터 방법에 의한 폼알데하이드 방출량과 비교적 방출 강도가 비슷한 결과를 나타내는 것을 확인 할 수 있었으며 이에 데시케이터법에 의한 폼알데하이드 방출량과 개발된 포집 공정에서 $163 \mathrm{~cm}^{2}$ 의 시편 2개(163 cm²)를 가지고 $100{ }^{\circ} \mathrm{C}, 1$ 시간 동안 포집 한 후 방출량을 측정하여 두 방법 간의 방출량에 대한 상관성을 조사 하였을 때 MDF(163 $\left.\mathrm{cm}^{2} \times 2\right)$ 의 경우 $\mathrm{r}^{2}=0.8988, \mathrm{~PB}\left(163 \mathrm{~cm}^{2} \times 2\right)$ 의 경우 $\mathrm{r}^{2}=0.8921$ 로 높은 상관관계를 보였다.

3. 앞선 결과들을 보았을 때 가속 포집 시험 공정에서 가장 신속하고 정확하게 폼알데하이드 방출량을 측정할 수 있는 조건은 $163 \mathrm{~cm}^{2}$ 시편 2개(163 $\left.\mathrm{cm}^{\prime} \times 2\right)$ 를 가지고 $100{ }^{\circ} \mathrm{C}, 1$ 시간 동안 시험하였을 때였으며 가속 포집 시험 공정의 활용성 검증 차원에서 한국건설생활환경시험연구원에 데시케이터 방법으로 시험의뢰 되어 실제 시험에 쓰이지 않았던 남은 시편들을 가지고 표준화된 가속 포집 시험 공정에 따른 시험 결과와 데시케이터 방법과의 결과와 비교 조사한 결과 $\mathrm{r}^{2}=0.8971$ 로 비교적 높은 상관관계를 나타내었다.

4. 하지만 데시케이터 방법과 가속 포집 시험 공정에 의한 방법에 대해 시험한 결과의 평균값을 비교하였을 때에는 대부분 가속 포집 공정방법 적용 시에 데시케이터 방법보다 다소 높은 결과 값을 나타냈으며 데시케이터 방법에 의한 방출량 결과에 비해 1 등급씩 높게 나오는 경우가 있었다.

5. 폼알데하이드 방출 등급이 한단계씩 높게 나오는 경우에 대해서는 생산 공장에서 품질관리 측면으로 보았을 때에는 충분히 적용 가능할 것이라고 판단되었다. 만약 개발된 본 공정으로 $\mathrm{E} 0$ 등급에 맞추어 품질관리를 한다면 데시케이터 방법에 의한 결과는 E0 등급 이상의 더 좋은 SE0 등급 방출량을 나타낼 수 있을 것이며, E1 등급 중 가장 낮은 방출량 범위에 맞추어 품질 관리를 한다면 E0 등급 수준의 관리가 가능할 것이라 판단되었다. 이에 본 공정을 생산 현장에서 활용 한다면 24시간의 시험 기간이 걸리는 데시케이터 방법을 대체하여 1 시간의 시험으로 폼알데하이드 방출량을 측정함으로써 보다 신속한 품질관리 가 가능할 것이라 판단된다. 